\title{
EXPERIMENTI DE LA EXCELENTISSIMA SIGNORA CATERINA DA FURLJI. KATARZYNA SFORZA I JEJ SPOSOBY NA PODKREŚLENIE URODY
}

Kobiety od wieków wiele uwagi poświęcały swojej urodzie, starając się zachować jak najdłużej młody, piękny i zdrowy wygląd ${ }^{I}$. W zależności od swojej pozycji społecznej i sytuacji ekonomicznej dysponowały większymi lub mniejszymi środkami pozwalającymi im nabywać produkty o właściwościach upiększających, które potem wykorzystywały do sporządzenia różnego rodzaju perfum, maści, kremów i pomad. Panie zajmujące wyższe szczeble drabiny społecznej z oczywistych względów miały więcej czasu i możliwości, aby poddawać się długotrwałym zabiegom kosmetycznym i kupować droższe produkty niż kobiety, które wywodziły się z niższych warstw. Trudniejsze warunki ekonomiczne często wymagały od tych ostatnich oprócz wykonania wszystkich obowiązków domowych także ciężkiej pracy w polu lub w zakładzie prowadzonym przez ojca czy męża.

Dbając o swoją urodę, kobiety wykorzystywały w pielęgnacji rośliny i minerały, o których właściwościach kosmetycznych były przekonane. Wiedzę na ich temat przekazywały sobie początkowo z pokolenia na pokolenie. $Z$ czasem, chociaż był to proces bardzo powolny spowodowany brakiem jednomyślności mężczyzn w kwestii kształcenia kobiet ${ }^{2}$, zaczęły powstawać traktaty, w których autorki notowały znane sobie przepisy mające pomóc w uzyskaniu gładkiej, białej jak marmur skóry, włosów blond, czarnych lub rudych, białych zębów i zadbanych ust.

Z powodu ograniczonego dostępu kobiet do edukacji zachowało się do czasów współczesnych niewiele traktatów z epoki średniowiecza, w których autorki poruszałyby kwestie związane z higieną i kosmetyką. Za jeden z pierwszych uznaje się traktat żyjącej w VI wieku

\footnotetext{
* Dr Anna Głusiuk - adiunkt w Katedrze Średniowiecza w Instytucie Nauk Historycznych i Społecznych Uniwersytetu Kardynała Stefana Wyszyńskiego. Zainteresowania naukowe koncentruje na edukacji, sytuacji i roli kobiety w epoce średniowiecza, medycynie i literaturze tej epoki. E-mail: a.glusiuk@uksw.edu.pl

1 Por. I. Rudowska, Kosmetyka wczoraj i dziś, Warszawa 1989, s.10-83.

2 Bernardino ze Sieny uważał, że jedynie dziewczęta z wyższych warstw społecznych powinny umieć pisać i czytać, natomiast nie powinno się tego uczyć dziewcząt zajmujących niższe szczeble drabiny społecznej. Por. E. Power, Donne nel medioevo, red. M. M. Postan, Jaca Book, Milano 19994, s. 74; eadem, L'educazione delle donne, w: Né Eva né Maria. Condizione femminile e immagine della donna nel Medioevo, red. M. Pereira, Zanichelli, Bologna 1981, s. 103. Menagier z Paryża zalecał naukę wszystkich kobiet. Por. E. Power, Donne nel medioevo, s. 74. Geoffroy de la Tour Landry uważał za konieczne, aby kobiety potrafiły czytać święte pisma. Por. Geoffroy Tour De La Landry, The Book of the Knight of La Tour-Landry: Compiled for the Instruction of His Daughters, London 1868, s. 117. Filip z Nawarry uważał, że edukacja powinna być zakazana wszystkim kobietom. Por. E. Power, Donne nel medioevo, s. 74.
} 
Metrodory $^{3} O$ chorobach kobiet $^{4}$, w którym autorka oprócz problemów ginekologicznych porusza również kwestię higieny i kosmetyki. Zachowany do czasów współczesnych manuskrypt przechowywany w Bibliotece Laurencjańskiej we Florencji jest jedynym egzemplarzem zawierającym tekst Metrodory ${ }^{5}$, lecz z pewnością nie jest on oryginałem spisanym w VI wieku'.

Drugą kobietą, której receptury zachowały się do czasów współczesnych, jest żyjąca w XI wieku Trotula z Salerno. Przypisywany jej traktat De passionibus mulierum ${ }^{7}$ składa się z trzech mniejszych dzieł: Liber de sinthomatibus mulierum, De curis mulierum i De ornatu mulierum, różniących się między sobą poruszaną w nich tematyką ${ }^{8}$. Ze względu na to, że wszystkie trzy traktaty wywodziły się z Salerno ${ }^{9}$ i dotyczyły zbliżonej problematyki, połączono je, uznając za ich autorkę właśnie Trotulę ${ }^{\mathrm{IO}}$.

Kolejną kobietą, której receptury zachowały się do czasów obecnych, pomimo że spisane przez nią karty zaginęły w nieznanych okolicznościach, jest żyjąca w Italii na przełomie XIV i XV wieku Katarzyna Sforza. Współcześni jej pisarze zaświadczali, że przyszła pani Forlì i Imola oprócz silnego charakteru i wielkiej inteligencji wyróżniała się również niepospolitą

\footnotetext{
Z powodu braku informacji na temat Metrodory zajmujący się nią naukowcy przyjmowali, że autorka traktatu żyła pomiędzy II a IV. Por. H. Parker, Women and Medicine, w: A Companion to Women in the Ancient World, red. S.L. James, S. Dillon, Malden, Oxford, Chichester 2012, s. 123; H.T. Parker, Women Doctors in Greece, Rome, and the Byzantine Empire, w: Women Healers and Physicians: Climbing a Long Hill, red. L.R. Furst, The University Press of Kentucky 1997, s. 138; I.D. Rowland, The amazing afterlife of Cleopatra's love potion, w: Cleopatra: A Sphinx Revisited, red. M.M. Miles, University of California Press 2011, s. 141. Giorgio del Guerra zauważa, że w swoim traktacie Metrodora cytowała żyjącego w VI wieku Aleksandra z Tralles. Por. Il libro di Metrodora sulle malattie delle donne e ricettario di cosmetica e terapia, ed. trad. it. G. Del Guerra, Milano 1953, s. 142, 147. Erica Maderna zakłada natomiast, że Metrodora żyła pomiędzy V a VI wiekiem. Por. E. Maderna, Medichesse. La vocazione femminile alla cura, Aboca 2014, s. 49.

4 Por. Metrodora, Medicina e cosmesi ad uso delle donne: l'antica sapienza femminile e la cura di sè, introduzione G. Del Guerra, Milano 1994. Na temat spisanych między innymi przez Metrodorę receptur por. A. Głusiuk, Dbałość o urodę kobiet na podstawie traktatów Metrodory z Bizancjum i Trotuli z Salerno, „Seminare”, 2018, nr 1, s. 145-154.

5 Traktat ten nie jest oryginalnym tekstem spisanym przez Metrodorę, ale jedynie jego kopią wykonaną przez anonimowego skrybę pomiędzy X a XIII wiekiem. Del Guerra zakłada, że traktat został sporządzony pomiędzy XII a XIII wiekiem. Por. Il libro di Metrodora, op. cit., s. 20. Anna Maria Ieraci Bio sugeruje natomiast, że traktat został napisany w Kalabrii pomiędzy X a XI wiekiem. Por. A.M. Ieraci Bio, Testi ginecologici tra Oriente ed Occidente I. Metrodora ed il Dynameron di Nicola Mirepso II. Una testimonianza italo-greca su una Quaestio medicalis salernitana, w: La Scuola Medica Salernitana. Gli autori e i testi. Convegno Internazionale (Università degli Studi di Salerno, 3-5 novembre 2004), red. D. Jacquart, A. Paravicini Bagliani, Firenze 2007, s. 298-299.

6 Niestety nie wiadomo, kiedy i w jakich okolicznościach zaginął oryginalny manuskrypt z VI wieku, ale można sądzić, że znajdujący się we Włoszech egzemplarz zawierający traktat $O$ chorobach kobiet jest tylko streszczeniem bardziej obszernego dzieła. Por. A.M. Ieraci Bio, Testi ginecologici tra Oriente ed Occidente, s. 299.

7 Trotula. Un compendio medievale di medicina delle donne, red. M. H. Green, Firenze 2009.

8 Liber de sinthomatibus mulierum dotyczy położnictwa i ginekologii; De curis mulierum omawia przede wszystkim problemy ginekologiczne, patologie występujące u dzieci i mężczyzn oraz kwestie związane z higieną i kosmetyką, a De ornatu mulierum porusza kwestie związane z higieną i kosmetyką. Na temat spisanych przez Trotulę receptur por. A. Głusiuk, Higiena kobiet w jedenastowiecznej Italii na podstawie nauk Trotuli z Salerno, w: Czystość i brud. Higiena w średniowieczu, red. W. Korpalska, W. Ślusarczyk, Bydgoszcz 2014, s. 97-109.

$9 \quad$ Trotula. Un compendio medievale..., s. 3.

10 Ibidem.
} 
urodą $^{\text {II }}$. Filip z Bergamo uznał ją za najpiękniejszą z kobiet ${ }^{12}$, Giuseppe Betussi' ${ }^{13}$ pisał o niej: „dziewica o wspaniałej urodzie”I4, a wenecki kronikarz Marin Sanudo wyraził się o Katarzynie, mówiąc: „ditta madama, fiola del duca Galeazzo di Milan, è bellissima donna”I5.

Liczba spisanych przez Katarzynę receptur sugeruje, że przykładała dużo uwagi do pielęgnacji i podkreślenia swojej urody. Zanim jednak zostaną przedstawione niektóre z jej receptur uznaje się za konieczne przybliżyć jej postać oraz przedstawić Experimenti, które informują, w jaki sposób żyjące w XV wiecznej Italii kobiety dbały o swoją urodę oraz jakich roślin i minerałów używały do jej podkreślenia.

\section{Katarzyna Sforza i jej Experimenti}

Katarzyna przyszła na świat w Mediolanie lub Pavii ${ }^{16}$ około roku I46 $3^{17}$ jako nieślubne dziecko księcia Mediolanu Galeazzy Marii Sforzy i Lukrecji Landriani ${ }^{18}$. W I466 roku zamieszkała na dworze Sforzów, a w wieku pięciu lat została zaadoptowana przez żonę Galeazzy, Bonę di Savoia, która opiekowała się nią i zadbała o jej edukację ${ }^{19}$. Jak wynika z listu z dnia 27 stycznia I469 roku pisanego przez Gotarda Panigarolę i adresowanego do Galeazzy, Katarzyna uczyła się razem z prawowitymi synami księcia Karolem i Aleksandrem pod kierownictwem nauczyciela Andreotta del Maino ${ }^{20}$.

Zgodnie z obyczajami ówczesnej epoki, o przyszłości Katarzyny zadecydował ojciec, który wybrał jej na męża syna Marc’Antonia Torellego, Onorata, ten jednak zmarł w młodym wieku $^{21}$. I7 stycznia I473 ${ }^{22}$ Galeazza doprowadził do zaręczyn Katarzyny z siostrzeńcem papieża Sykstusa IV, Gerolamem Riario ${ }^{23}$, a w I477 roku odbył się w Rzymie ich ślub ${ }^{24}$.

11 Por. N. Graziani, G. Venturelli, Caterina Sforza, Milano 2001, s. 6: „Lettere, cronache, note diplomatiche, relazioni militari, carte d'archivio le più varie e persino un ricettario di salute e di bellezza ci parlano di lei, ora esaltata come «femina do grandissomo animo et core, sine dubio Prima Donna d'Italia», ora bollata come «tygre» e «foemina sanguinaria et tyranissa»".

12 Vita di Caterina Sforza Riario contessa d'Imola e signora di Furli descritta in tre libri dall'abate Antonio Burriel, t. 1, Bologna 1795, s. 29: ,est quippe haec Caterina inter mulieres nostri saeculi formosissima, et eleganti aspectu, ac per omnes corporis artus mirifice ornata est".

13 Por. Libro di M. Giovanni Boccaccio delle donne illustri. Tradotto di latino in volgare per M. Giuseppe Betussi, con una giunta fatta dal medesimo, d'altre donne famose. E un'altra nuova giunta fatta per M. Francesco Serdonati d'altre donne illustri. Antiche e moderne. Con due tavole una de nomi, e l'altra delle cose più, Fiorenza per Filippo Giunti 1596, s. 589-591.

14 Ibidem, s. 589.

15 „Wspomniana pani, córka księcia Galeazzy, jest najpiękniejszą kobietą”. Jeśli nie zaznaczono inaczej thumaczenia cytatów z języka włoskiego pojawiających się w całym artykule dokonała autorka pracy. N. Graziani, G. Venturelli, op. cit., s. 155.

16 Por. P. D. Pasolini, Caterina Sforza, t. 1, Roma 1893, s. 39.

17 Antonio Burriel podaje rok 1462. Por. Vita di Caterina Sforza Riario..., s. 2.

18 Por. ibidem, s. 2-3.

19 Por. P. D. Pasolini, Caterina Sforza, t. 1, s. 40.

20 Por. ibidem, s. 41, nota 1.

21 Por. Vita di Caterina Sforza Riario..., s. 7-8.

22 Por. P. D. Pasolini, Caterina Sforza, t. 1, s. 45-46.

23 G. Franceschini, Caterina Sforza e il tramonto della Signoria su Imola e Forli, Bologna 1967, s. 9: „Questa mattina de domenica - scriveva il duca a Roma il 17 gennaio 1474- ad hore diciotto avemo dato nostra figliola Caterina per legitima sposa al conte Hieronimo".

${ }^{24}$ Por. P. D. Pasolini, Caterina Sforza, t. 1, s. 82; N. Roatti, Della Famiglia Sforza, t. 2: Donne illustri di Casa Sforza, Roma 1794, s. 35. 
W maju I477 roku Katarzyna wraz z mężem przybyła do miejscowości Imola, a w roku I480 małżonkowie otrzymali od papieża miejscowość Forlì25. Po śmierci Sykstusa IV w sierpniu I484 roku $^{26}$, obawiając się wyboru nowego papieża, który nie sprzyjałby interesom Riarów, Katarzyna zajęła Zamek Anioła ${ }^{27}$, podczas gdy Gerolamo z wojskiem stacjonował w Rzymie. Kardynałowie, nie chcąc w zaistniałej sytuacji dokonać wyboru kolejnego następcy Piotra, w zamian za opuszczenie miasta przez wojska Riarów zaproponowali Gerolamo 8000 dukatów oraz zagwarantowali mu utrzymanie inwestytury w Imoli i Forli ${ }^{28}$. Katarzyna, licząc na dużo większe zyski, początkowo nie chciała ustąpić, jednak zmuszona przez męża do przyjęcia warunków opuściła Rzym i powróciła do Forlì.

I4 kwietnia I488 roku w wyniku zawiązanego przez ród Orsich spisku zamordowano Gerolamo $^{29}$, a Katarzynę, która przebywała wówczas w zamku wraz z matką, siostrami i dziećmi, zatrzymano podczas zamieszek ${ }^{30}$. Na krótko przed aresztowaniem Katarzynie udało się wysłać do Bolonii i Mediolanu wiadomość z prośbą o pomoc wojskową ${ }^{3 \mathrm{I}}$. Świadomi możliwych represji ze strony zwolenników rodu Riarów przedstawiciele miasta postanowili oddać Forlì papieżowi ${ }^{32}$. Orsi, aby wzmocnić swoją pozycję, planowali zająć dwa strategiczne zamki Ravaldino i Schiavonia znajdujące się nadal w rękach wiernych Katarzynie kasztelanów, której podstępem udało się schronić w pierwszym z nich ${ }^{33} \cdot 30$ kwietnia I488 roku Katarzyna objęła rządy w Forlì w imieniu swojego najstarszego syna Oktawiana ${ }^{34}$, a kilka miesięcy później poślubiła szlachcica Giacomo de Feo, którego zamordowano 27 sierpnia I495 $\mathrm{r}^{35}$. Według zachowanych informacji wiadomo, że w I496 roku Katarzyna wyszła za mąż za Jana Popolana Medyceusza ${ }^{36}$, a 6 kwietnia 1498 roku przyszedł na świat ostatni z synów Katarzyny Jan de’Medici ${ }^{37}$.

W I499 roku wojska francuskie najechały na Italię, co wykorzystał wrogo nastawiony do rodu Riariów papież Aleksander VI Borgia pragnący wzmocnić swoje wpływy na terenach położonych na północ od Rzymu. 24 listopada I499 roku miejscowość Imola poddała się wojsku Cezara Borgii, a I9 grudnia uczyniła to także Forlì. Katarzyna schroniła się na zamku Ravaldino, walcząc do I2 stycznia I50o roku. Pani z Forlì spędziła rok w Zamku Anioła w Rzymie jako więzień Borgiów, z którego została uwolniona dopiero po podpisaniu

\footnotetext{
25 Por. Vita di Caterina Sforza Riario..., s. 46.

26 Por. ibidem, s. 125-126.

27 Por. ibidem, s. 126: „Ai 14, dice il Diario del Nantiporo, venne il Conte Jeronimo con tutto il Campo a Roma, ed alloggiò in Prata: e la Contessa entrò in Castel Santangelo"; P. D. Pasolini, Caterina Sforza, t. 1, s. 148.

28 Por. ibidem, s. 156.

29 Cronaca di Anonimo Veronese 1446-1488, red. G. Soranzo, Venezia 1915, s. 459: „lo feriron de molte ferite de pugnali in modo ch'el morì subito; fu adì XIIII de aprille MCCCCLXXXVIII"; Por. P. D. Pasolini, Caterina Sforza, t. 1, s. 199; N. Roatti, op. cit., s. 37.

30 Por. P. D. Pasolini, Caterina Sforza, t. 1, s. 210; N. Graziani, G. Venturelli, op.cit., s. 103.

31 Por. N. Graziani, G. Venturelli, op.cit., s. 103.

32 Por. N. Roatti, op. cit., s. 37.

33 Por. N. Graziani, G. Venturelli, op.cit., s. 104-108.

34 Por. K. Chłędowski, Rzym: Ludzie odrodzenia, Warszawa 1957, s. 169; P. D. Pasolini, Caterina Sforza, t. 1, s. 267; N. Graziani, G. Venturelli, op.cit., s. 131.

35 Por. P. D. Pasolini, Caterina Sforza, t. 1, s. 360-361.

36 Por. idem, Caterina Sforza, t. 2, Roma 1893, s. 14.

37 Por. N. Graziani, G. Venturelli, op.cit., s. 216.
} 
dokumentów, w których zrzekała się swoich dóbr ${ }^{3^{8}}$. W I50I roku udała się do Florencji3 ${ }^{39}$, gdzie na życzenie brata Jana Popolana, Lorenza di Pier Francesca, zamieszkała w pałacu swojego ostatniego męża ${ }^{40}$, który zmarł w wyniku choroby jeszcze w I 498 roku $^{41}$. Katarzyna zmarła 28 maja 1509 roku $^{42}$ i została pochowana w klasztorze Santa Maria delle Murate we Florencji43.

Katarzyna na dworze Sforzów otrzymała bardzo dobre wykształcenie i możliwe, że już tam zetknęła się z alchemią i zainteresowała się medycyną, chemią, właściwościami ziół i minerałów. $Z$ zachowanych listów ${ }^{44}$ wynika, że, pragnąc zdobyć nowe informacje na interesujące ją tematy, prowadziła rozległą korespondencję z alchemikami, zielarzami i szlachetnie urodzonymi damami ${ }^{45}$. Oprócz wymiany informacji i receptur, w listach znajdowały się również prośby o przesłanie przygotowanych przez nią kosmetyków. Przykładem może być list z 5 maja I502 roku, w którym Madonna Costanza prosi między innymi o przesłanie jej wykonanych przez Katarzynę perfum ${ }^{46}$. W innym liście, który pani z Forlì otrzymała od markizy Mantui, znajdowała się sekretna receptura na krem do twarzy i rąk. W zamian za nią Katarzyna przesłała markizie informację, $w$ jaki sposób otrzymać złoto ${ }^{47}$. Wiadomo również, że pani z Forlì była w stałym kontakcie ze swoim dostawcą ziół Ludovico Albertinim, który musiał darzyć ją wielkim zaufaniem, skoro wysyłał zamawiane przez nią składniki nawet wtedy, gdy nie otrzymywał natychmiastowej zapłaty. Z zachowanych dokumentów wynika bowiem, że po śmierci Katarzyna była mu winna 587 florenów ${ }^{48}$.

Jak zaznaczył Pier Desiderio Pasolini, który jako pierwszy wydał zbiór receptur Katarzyny, nauka i prowadzone przez nią eksperymenty interesowały ją do tego stopnia, że znajdowała na nie czas nawet $\mathrm{w}$ trakcie prowadzonej wojny ${ }^{49}$. Informację tę potwierdza list z 2 listopada I499 roku pisany podczas oblężenia zamku Ravaldino przez Cezara Borgię, w którym Katarzyna zwraca się do Francesco Fortunato z prośbą o przesłanie jej pewnych składników potrzebnych do planowanego przez nią eksperymentu ${ }^{50}$.

Pani z Forlì zapisywała receptury zarówno swoje jak i te, które otrzymała od innych, tworząc w ten sposób niewielką książeczkę ${ }^{51}$, która niestety zaginęła w nieznanych okolicz-

\footnotetext{
38 Por. ibidem, s. 293-295.

39 Por. ibidem, s. 301-302.

40 Por. ibidem, s. 303.

41 Por. P.D. Pasolini, Caterina Sforza, t. 2, s. 27.

42 Por. idem, Caterina Sforza, t. 3, Roma 1893, s. 548.

43 Por. idem, Caterina Sforza, t. 2, s. 342.

44 Por. Gli Experimenti de la ex.ma S.ra Caterina da Furlj, matre de lo inllux.mo signor Giovanni de Medici, copiati dagli autografi di lei dal conte Lucantonio Cuppano colonnello ai servigli militari di esso Giovanni de’Medici detto delle Bande Nere, Imola 1894, s. 5-11.

45 Por. E. Maderna, op. cit., s. 127.

46 Por. Gli Experimenti..., s. 9: „Madonna Costanza prga V. Ex.tia a mandargli qualche profumi et polvere di cipri".

47 Por. P.D. Pasolini, Caterina Sforza, t. 2, s. 377.

48 Gli Experimenti..., s. 5: „,e finalmente la somma di oltre 587 fioreni di cui era ancora creditore «per robbe date a sua ill.ma Signora in Forlì ... de la mia botega etc.» dimostra che egli era specialmente caro a Caterina, e che essa continuò a valersi di lui per quelle sue ricerche, per quei suoi esperimenti, i quali, malgrado la politica e la guerra, assorbivano, a quanto pare, gran parte dei suoi pensieri e della sua vita intellettuale e privata".

49 Por. ibidem, s. 5.

50 Por. ibidem, s. 8.

51 Por. P.D. Pasolini, Caterina Sforza, t. 2, s. 377.
} 
nościach. Zachowaną kopię wykonaną w 522 roku przez Lucantonia Cuppano pełniącego służbę wojskową u najmłodszego syna Katarzyny Jana de’Medici skonsultował Pier Desiderio Pasolini, który w I894 roku opublikował w I02 egzemplarzach zbiór receptur, nadając mu tytuł Experimenti de la Excelentissima Signora Caterina da Furlj matre de lo Illuxtrissimo Signor Giovanni de Medici. Zbiór składa się z ponad 400 receptur medycznych, farmakologicznych, chemicznych, perfumeryjnych i kosmetycznych ${ }^{52}$, spisanych częściowo po łacinie, a częściowo w języku wernakularnym. Należy dodać, iż niektóre z receptur Katarzyny były przez nią uważane za tak ważne, że spisała je, używając do tego znanego tylko jej szyfru.

\section{Dbałość o urodę kobiet}

Pier Desiderio Pasolini we wstępie do opublikowanego w I894 roku dzieła Katarzyny napisał, że spisane przez nią receptury ukazują zwyczaje epoki oraz przedstawiają poziom, na jakim znajdowała się wówczas nauka ${ }^{53}$. Dzięki biegłej znajomości właściwości kosmetycznych wielu roślin i minerałów Katarzyna podawała liczne przepisy na uzyskanie gładkiej i pozbawionej zbędnego owłosienia skóry, pięknych blond lub czarnych włosów, jasnej cery czy białych zębów. W swoich przepisach stosowała wiele różnych składników, o których właściwościach kosmetycznych była przekonana, jak na przykład orzechy, czarny bez, malwę, mak, pokrzywę, rumianek, czosnek, piołun, rutę, olej z oliwy, mleko z migdałów i wodę różaną. Analizując spisane przez nią receptury, zauważa się różny stopień trudności w przygotowaniu kosmetyków, od najprostszego zmieszania niezbędnych składników, przez ich starcie i zagotowanie, aż po proces destylacji, co pozwala sądzić, że kierowała swoje porady zarówno do kobiet bardziej doświadczonych jak i do tych, które dopiero zaczynały interesować się wyrobem własnych środków upiększających.

\subsection{Cera}

Duża liczba przepisów na piękną, pozbawioną wszelkich plam i krost cerę świadczy o tym, jak wielką uwagę Katarzyna przykładała do dbania o skórę twarzy. W jednym ze swoich najprostszych przepisów pisała: „weź jedną uncję soli zasadowej lub zwykłej, zagotuj ją w wodzie z rzeki. Następnie oczyść, przelewając przez filc i wlej do szklanego naczynia i używaj”54. W innym miejscu zalecała: „,weź korzeń bukwicy zwyczajnej, ugotuj ją w oleju i tym myj twarz”55. W kolejnej recepturze natomiast pisała: „weź żywicę, ocet, słój miodu i wymieszaj składniki i zrób maść, a kiedy idziesz spać posmaruj tym twarz, a rano przemyj ją czystą wodą" ${ }^{6}$. Kobietom pragnącym cieszyć się gładką cerą Katarzyna sugerowała przygotowanie pewnego rodzaju ówczesnego peelingu: „weź cyclamen hederifolium, obierz tak, aby był czysty, sproszkuj i pocieraj nim twarz"s7.

\footnotetext{
52 Por. E. Maderna, op.cit., s. 127.

53 Por. Gli Experimenti..., s. 3.

54 Por. ibidem, s. 33: "Piglia sale alklj (alcali) uel sale comuno L. vna et fallo Bollir con un poco de aqua de fiume. De poi purgalo con feltro et ponilo in vaso de vetrio et adopera".

55 Ibidem, s. 33: „Piglia la radice della Bertonica et falla cocere in oleo et con questo lauate la faccia”.

56 Ibidem, s. 34: „Piglia, galbano, aceto, vitrum melle et mistica omne cosa insieme et fallo a modo unguento, et quando vai a dormire ognete la faccia et la matina lauate con acqua chiara".

57 Por. ibidem, s. 33: „Piglia pane porcino et radilo cusi che sia monda, et fanne poluere et con questa poluere, frega la facia".
} 
Kobietom, które chciały mieć białą i lśniącą jak srebro skórę, Katarzyna zalecała użyć między innymi białka jaja, słoniny z wieprza, zwykłego oleju i octu. Składniki należało wymieszać i uzyskaną maścią posmarować twarz, szyję i dłonie ${ }^{5}$. Do innego przepisu konieczne było użycie miękiszu chleba, który mieszano z białkiem kurzego jaja i następnie dodawano do octu. Powstałą w ten sposób maseczkę nakładano na skórę59. W innym przepisie Katarzyna zalecała zagotować z mocnym octem tlenek ołowiu, przedestylować przez filc i otrzymanym płynem przemywać twarz, która stawała się biała jak śnieg ${ }^{60}$. Podobny efekt zdaniem Katarzyny dawało użycie białka świeżych jaj, które destylowano w alembiku. Otrzymanym płynem, który był skuteczny w usuwaniu niepożądanych blizn, przemywano twarz ${ }^{6}$. W innej recepturze pani z Forlì zalecała: „weź dużo kwiatów bobu i zrób z nich wodę destylowaną, i myj nią twarz"62. W kolejnym przepisie sugerowała, by wykorzystać skorupki jaj, które należało dokładnie rozdrobnić i przedestylować na małym ogniu. Otrzymaną w ten sposób wodą myto twarz ${ }^{63}$. Paniom pragnącym mieć cerę jak kryształ sugerowała: „weź jaskółki, destyluj je wraz z piórami i wnętrznościami, włóż dłoń i przemyj twarz przed jedzeniem rano i wieczorem" ${ }^{4}$.

Kobietom, którym zależało na zdrowej i zaróżowionej cerze, Katarzyna zalecała między innymi, by włożyć do dobrego wina obrany korzeń mirry i wypić taką miksturę ${ }^{65}$. Według innego przepisu, w celu uzyskania zaróżowionej cery należało użyć starej kości słoniowej, sproszkować ją, dodać do wina lub wody i pić przez dwadzieścia dni ${ }^{66}$. Piękną i zadbaną skórę według receptur Katarzyny otrzymywano też, przemywając cerę płynem powstałym z mocnego octu i pokrojonych cytryn. Składniki wkładano do szklanego alembiku, do którego dosypywano w niewielkiej ilości goździków zarówno sproszkowanych jak i w całości ${ }^{67}$.

Paniom pragnącym usunąć szpecące twarz plamy Katarzyna radziła użyć rośliny znanej jako aristolochia serpentaria (roślina z rodziny kokornakowatych), którą należało rozdrobnić i gotować w winie tak długo, aż pozostanie jedna trzecia płynu, którym przemywano

\footnotetext{
58 Por. ibidem, s. 33: "Piglia albume de oua de galline Lardo de porco raspato, oleo comuno aceto o uero agresti et mestica omne cosa insieme a modo de confretione et con questo vgne la faccia, el collo, le mano, et drento si tu voli, che Deuenteranno Bianche et lucente come vno argento".

59 Por. ibidem, s. 33: "Piglia mollica de pane albume de ouo et mistica insieme et ponilo in aceto per doi di naturale et poi usala a tuo piacere".

60 Por. ibidem, s. 33: "Piglia litargirio L. vna aceto fortissimo vno Bocale fallo bollir insieme alquanto, de poi destilla per feltro. De poi piglia vn poco de questa aqua et bagniate et frega el volto et venera Bianca come neue".

61 Por. ibidem, s. 32: „Piglia chiara de oua fresca quante tu voli et falli destillare a lanbicco et con quella aqua laua la faccia, che e perfettissima a far Bello et laua tutti li segni et cicatrice della faccia".

62 Ibidem, s. 32: „Piglia flori de fava quantitta et fanne aqua destilata et con questa aqua Lavati la faccia”.

63 Por. ibidem, s. 33: "Piglia le scorze delle oue et pistale Bene et falle destillar alabicco con foco lento et con questa aqua lauate la faccia".

${ }^{64}$ Ibidem, s. 42: "Piglia delle irondine et destillale con le piume et con le interiore et de questa metti in la mano, et bagniate el viso, inante el cibo la mattina et sera".

65 Por. ibidem, s. 25: „Piglia radice di mira el sole e radila e metila in bon vino e beui quel vino che ti fara bonissimo colore e bello".

${ }^{66}$ Por. ibidem, s. 54: „Piglia della rasura dello auorio vechio et beuini con vino o con acqua per vinti di et e prouato".

67 Ibidem, s. 40: „Piglia aceto forte Limoni tagliati in pezzi et ponilo alanbicco de vetrio et ponili de garofani fatti in poluere et garofani integri poco de vno et delaltro et metti ogni cosa alanbicco et salua la aqua che e perfetta et adopera".
} 
skórę twarzy ${ }^{68}$. W podobnym przepisie radziła: „weź korzeń aristolochiae serpentariae, gotuj w winie tak długo, aż zredukuje się do połowy, potem przelej i umyj tą wodą twarz"69. W innym miejscu pisała, aby użyć korzenia kosaćca, który gotowano tak długo, aż woda zredukowała się do połowy i otrzymanym płynem przemywano cerę ${ }^{70}$.

\subsection{Dłonie}

W przypadku popękanej skóry dłoni Katarzyna sugerowała środek zaradczy, który należało przygotować z soku pokrzywy z dodatkiem niewielkiej ilość soli. Wszystkie składniki mieszano i otrzymaną pastą smarowano popękane miejsca ${ }^{71}$. W innej recepturze radziła użyć, w takich samych proporcjach, oleju, wosku, tłuszczu z kury i żywicy, które gotowano, studzono i następnie używano ${ }^{72}$. Kobietom pragnącym cieszyć się białą skórą twarzy i dłoni Katarzyna zalecała: „weź i ugotuj w wodzie liście i korzenie pokrzywy, i tą wodą myj dłonie i twarz, wtedy staną się białe i miękkie"73. W innym miejscu sugerowała, aby sięgnąć po następujące składniki: tłuszcz z knura, trzydzieści białek jaj, dwadzieścia cytryn oraz świeży, delikatny i tłusty ser. Wszystkie produkty należało rozdrobnić w moździerzu, przełożyć do szklanego alembiku i postawić na niewielkim ogniu. Przed użyciem otrzymanego płynu Katarzyna zalecała najpierw umyć starannie skórę w czystej wodzie i następnie dobrze ją wytrzeć do sucha. Dopiero po oczyszczeniu rąk polecała użyć otrzymaną wodę, która - jak zapewniała - jest wspaniała i ma wiele cennych właściwości ${ }^{74}$.

\subsection{Włosy}

Katarzyna w swojej książeczce zapisała również wiele przepisów instruujących, w jaki sposób uzyskać włosy koloru blond i czarne. Przez współczesnych jej malarzy pani z Forlì była przedstawiana jako blondynka o długich, prostych włosach, jednak trudno stwierdzić, czy był to jej naturalny kolor, czy też uzyskiwała go, stosując którąś z zanotowanych przez siebie receptur.

W jednym z przepisów kobietom pragnącym cieszyć się włosami koloru blond Katarzyna radziła: „weź liście bluszczu pospolitego i gotuj je w kosmetyku, który robisz w domu, gotuj

\footnotetext{
68 Ibidem, s. 25: "Piglia radice de serpentaria e tritela et cocila in uino Tanto che rientri la terza parte poi il cola e lauati la faccia cum esso per in sin che serai libero".

69 Ibidem, s. 42: "Piglia radice di serpentaria et cocila in vino et bolla tanto che calli la mita poi colala et lauate el viso con questa aqua".

70 Por. ibidem, s. 32: „Piglia, radicem Jazole et bollila in la aqua per sino se consuma la meza parte da poi purgala et con quella aqua laua la faccia et serai liberata".

71 Ibidem, s. 42: "Piglia succo de ortiga et vn poco de sale et mestica insieme bene et ognete le mano Doue sonno Crepate".

72 Ibidem, s. 70: "Piglia oleo Comune et Cera noua con grasso de gallina et mastice an., tanto de vno Come de Laltro et mettilo in vn vaso Al foco a bollir vn poco et lassa freddare poi adopera".

73 Ibidem, s. 25: "Piglia foglie e radice de urtcica e fa bulire in acqua et cum quel acqua lauate le mano e il uolto e diuenteranno bianche et morbide".

${ }^{74}$ Ibidem, s. 69: "Piglia L. 1 de assognia de porco maschio et chiara de oua trenta et limoni numero venti poi piglia vna forma de Cascio fresca che sia tenera et grassa poi pista omne cosa bene in vno mortaro, poi ponilo al Lambicco de vetrio et dalli foco Lento, et caua Lacqua Quale adopera in questo modo, Laua prima Le mano con aqua netta et sciutta bene poi Bagna con ditta acqua, che vederai cosa mirabilissima et e de tanta virtu che simile ognaltro Loco per Brutto che sia adoperando in simil modo fa amarauiglia Bello".
} 
je dobrze i tym myj głowę, a uzyskasz piękne włosy”75. Paniom chcącym otrzymać jeszcze lepszy efekt radziła wykonanie własnego kosmetyku: „weź drewno bluszczu, spal je i zrób z niego popiół, i z tego popiołu i wspomnianych liści zrób swój kosmetyk i używaj’’76.

W innym przepisie, aby uzyskać włosy koloru złota, zalecała użyć korzenia bluszczu, który obierano, drobno siekano, wyciskano z niego sok do alembiku, a następnie otrzymaną wodą moczono włosy77. W kolejnej recepturze zalecała: „weź cynober, szafran, siarkę i przedestyluj w alembiku. Kiedy umyjesz głowę, czesząc się na słońcu, zamaczaj często grzebień w tej wodzie i w ten sposób, jak wyschnie na słońcu, będzie piękna jak złoto"78. Kobietom chcącym uzyskać włosy koloru czarnego Katarzyna proponowała użyć niedojrzałe orzechy, które dzielono na cztery części i wkładano do alembiku. Uzyskaną wodą moczono włosy, które stawały się czarne ${ }^{79}$.

Kobietom, które chciały mieć ładne, kręcone włosy, Katarzyna zalecała: „weź rogi kozła, spal je, sproszkuj i dodaj zwykłego oleju. Wymieszaj dokładnie i kiedy myjesz włosy, natłuść dobrze głowę; po kilku zastosowaniach włosy staną się kręcone"8o.

W przypadku utraty włosów, w celu przyśpieszenia ich, odrostu Katarzyna radziła schwytać zielone żaby i jaszczurki, obciąć głowę i ogon oraz użyć pszczół produkujących miód. Wszystkie składniki w takich samych proporcjach należało prażyć na ogniu, a uzyskany proszek dodać do oleju z żółtkami jaj. Uzyskaną substancją smarować te miejsca, w których miały wyrosnąć włosy ${ }^{8 \mathrm{I}}$. W innej recepturze Katarzyna zalecała: „weź w takich samych proporcjach chleb jęczmienny i sól, upraż i sproszkuj; następnie weź tłuszcz niedźwiedzi, rozgnieć i dobrze wymieszaj, i posmaruj miejsce, gdzie chcesz, aby odrosły" 82 . W innym miejscu pisała, aby użyć tłuszczu kreta, pszczół produkujących miód oraz trochę surowego miodu. Wszystkie składniki należało wymieszać, bardzo dobrze rozgnieść i zrobić z nich maść, którą smarowano miejsca, w których miały wyrosnąć włosy ${ }^{83}$. Na odrost włosów

\footnotetext{
75 Ibidem, s. 59: "Piglia delle foglie di edera et falle Bollir in lissia cio e in quella che tu fai in casa et che Bolla Bene et con quella Lauati el capo et farai li capelli belli".

76 Ibidem, S. 59: , et volendo far meglio piglia del Legno de hellera et Brusalo et fanne Cenere et con quella cenere et ditte foglie fa la tua lissia et adopera".

77 Ibidem, s. 63: „Piglia Radiche de ellera et radile Bene et tritale menute et cauane aqua per Lanbicco et con ditta acqua Bagnia el capo con vna spognia et in otto giorni veniranno come oro".

78 Ibidem, s. 62: „Piglia cinabro zaffrano et solfo et fa destillare queste cose per lanbicco et Quando te hai lauato el Capo, pettinate Al Sole et Bagna el pettine spesso in Questa acqua stillata et cusi te asciutta al Sole et verra bella come oro".

79 Por. ibidem, s. 67: „Piglia delle noce Quando comenzano a fare lo gaton et tagliale in quattro pezzi poi taglia via quel poco de mezzo, poi poni alanbicco et fanne Acqua, poi con quella acqua Bagniate la Barba et peli bene, che la farai negrissima, et sepius est experta".

${ }^{80}$ Ibidem, s. 58: "Piglia Corna de Castrone et Brusali et fanne poluere poi piglia de lo olio comune et mestica inseme Benissimo et come te laui la testa ogneti Bene lo Capo con lo olio in poche volte verranno Riccj.".

81 Ibidem, s. 60: "Piglia rane et Lucerte uerde et tagliali La testa et la coda, et ape che fanno lo mele tanto de vno Quanto de Laltro et Brusciali, o uero seccali in una olla noua in forno, et quella poluere Destempera con olio de Rossi De oui et de quello ogni doue tu voli che nasceranno li capilli et peli et e Certo".

82 Ibidem, s. 59: „Piglia pane de orzo et sale et carta tanto de vno Quanto de Laltro et brusali et fanne poluere, poi habbi del grasso de orso et pista et incorpora, Bene et ogne El loco Dove voli che nasceranno".

83 Ibidem, s. 60: „Piglia grasso de talpa et dalle ape che fanno el mele et vn poco de mele crudo, et mestica tutto inseme et pistale molto bene et fa a modo de onguento con el quale ogni doue tu voli che nasca peli o capelli che sensa dubio nasceranno".
} 
skuteczny zdaniem Katarzyny był także tłuszcz konia ${ }^{84}$ oraz rzepik rozgnieciony w kozim mleku ${ }^{85}$.

W swoim zeszyciku Katarzyna zapisała również kilka przepisów na skuteczny, jej zdaniem, środek depilacyjny. W jednej z receptur radziła: „,weź jaskółki i poddaj je destylacji i tą wodą namocz miejsce, z którego chcesz usunąć włoski i włosy"86. W innym miejscu podała przepis na pastę depilującą, w skład której wchodziło wapno gaszone, aurypigment i ałun potasowy. Wszystkie składniki należało dokładnie sproszkować, wyrabiać z moczem i smarować te miejsca, z których chciano pozbyć się zbędnego owłosienia. Czas trzymania pasty na skórze był równy czasowi potrzebnemu do odmówienia dwa razy modlitwy „Ojcze nasz" ${ }^{87}$.

\subsection{Zęby}

Dużo uwagi poświęciła Katarzyna higienie jamy ustnej. W jednej z receptur radziła: „weź rogi koziołków, rozdrobnij je, sproszkuj, gotuj w białym winie tak długo aż całkowicie wyparuje i pozostanie sam proszek i tym proszkiem pocieraj zęby i dziąsła" "88. Inny środek składał się ze zwęglonej łodygi rozmarynu, którą sproszkowywano, a otrzymanym proszkiem posypywano lniany materiał, którym następnie pocierano zęby ${ }^{89}$. W innym miejscu pisała: „weź biały marmur, biały koral, kość mątwią, sól, kamień szlachetny, kadzidło, żywicę i sproszkuj dokładnie każdy z produktów i przesyp proszek do materiałowego woreczka [...], i pocieraj nim zęby, i potem umyj dobrym winem, następnie wytrzyj kawałkiem szkarłatnej tkaniny"90. Inny przepis wymagał użycia korala i ałunu potasowego. Oba składniki prażono, rozdrabniano i przesiewano przez sito ${ }^{91}$. Według kolejnej receptury należało użyć soli, ałunu i saletry. Wszystkie składniki rozcierano i przesypywano do alembiku. Jak zaznacza Katarzyna, pierwsza otrzymana z wymienionych składników ciecz nie nadawała się do użycia. Dopiero drugą można było wykorzystać, ale należało ją stosować dwa razy w tygodniu ${ }^{92}$.

\footnotetext{
84 Ibidem, s. 62: „Prendi del grasso del cauallo et ogni Doue voli che manchino li peli et veniranno”.

85 Ibidem, s. 57: „Piglia agrimonia pista con latte de Capra et adopera nel sopra detto modo che sensa dubbio nasceranno".

86 Ibidem, s. 65: „Piglia delle yrondine et falle destillare et con quella Acqua Bagna el loco che tu voli che vadano via li peli et li capelli che e cosa probatissima".

87 Ibidem, s. 64: „Piglia Calcina uiua on. doi orpimento on. 1 Lume de rocco tanto de uno Quanto Delaltro come vna castagnia et spolueriza tutto Benissimo, poi impasta con orina et inpasta doue voli che caschino et Lassa star tanto che Dichi Doi pater nostri pol Lava".

88 Ibidem, s. 67: "Piglia Cornetti de Capretti et pistali et fanne poluere et falla Bollir in vino Bianco fin tanto che se consuma tutto el vino, et che resti poluere et con quella poluere fregati li denti e le gengiue".

89 Ibidem, s. 68: „Piglia del gambo del Rosmarino et fanne carboni, et da questi fanne poluere setacciata et metti ditta poluere in vna pezza de Lino et sfrega spesso li denti".

90 Por. ibidem, s. 68: „Piglia marmo Bianco, Corallo Bianco, osso de seppia sal gemma incenso, et mastice polueriza Bene ogne cosa et metti la ditta poluere in un saccuccio de tela [...] et con esso frega li denti poi laua con Buon vino, poi frega con una pezzetta de panno Scarlatto".

91 Por. ibidem, s. 68: „Piglia Corallj et Lume de rocco Brusando et macinato molto Bene et passa per setaccia et Adopera".

92 Por. ibidem, s. 68: „Piglia Sal Comune on.sei Alume Salnitro an. on. 3. pista inseme et fa acqua a Lambicco, la prima acqua che viene non e Bona, ma la seconda e Bona, et prima fatte nettar li denti poi usa questa acqua Doi volte la settimana".
} 


\section{Zakończenie}

Spisane przez Katarzynę Sforzę receptury, opublikowane w I894 roku przez Piera Desideria Pasoliniego jako Experimenti de la Excelentissima Signora Caterina da Furlj matre de lo Illuxtrissimo Signor Giovanni de Medici, ukazują, w jaki sposób żyjące w XV-wiecznej Italii kobiety dbały o swoją urodę i jakich produktów używały do przygotowania kosmetyków. Przedstawione receptury ukazują szeroką wiedzę Katarzyny na temat właściwości kosmetycznych różnych roślin i minerałów, które wykorzystywała w tworzeniu swoich produktów upiększających, oraz prezentują jej umiejętności konieczne do ich przygotowania. W przedstawionych przepisach zauważa się różny stopień trudności, co pozwala sądzić, że kierowała swoje porady zarówno do kobiet biegłych w tworzeniu kosmetyków jak i do tych mniej doświadczonych. Ponadto zanotowane przez nią informacje na temat skuteczności zapisanych przepisów pozwalają sądzić, że sama również korzystała z niektórych z nich.

\section{Experimenti de la Excelentissima Signora Caterina da Furlji. Catherine Sforza and her methods to underline beauty Summary}

In I894, Pier Desiderio Pasolini published notes on the beauty of women written by Catherine Sforza. Unfortunately the original text written by Catherine disappeared in unknown circumstances but in 522 Lucantonio Cuppano had seen the original and made one copy which was later consulted and published by Pasolini who gave it the tittle Experimenti de la Excelentissima Signora Caterina da Furlji. This writing - next to the work of Metrodora and Trotula of Salerno - is one of the oldest texts written by women, which is preserved for our time. This work shows that Catherine must have received an excellent education as she was interested in medicine, alchemy and property of herbs and minerals. The lecture on her recipes shows that she prepared her cosmetics for herself but she also sent them to others. Her recipes show her knowledge of the property of many herbs and minerals. Probably she thought about publishing her notes as we can find there some easy formulas (for beginners) where it was necessary only to add and mix the products. But there are also more complicated instructions where it was necessary to know, for example the process of distillation etc. Her writings show how in the $55^{\text {th }}$ century women in Italy cared about their beauty and which herbs and minerals to use to make their cosmetics.

Keywords: Catherina Sforza, beauty, recipes, herbs, minerals

\section{BIBLIOGRAFIA}

Teksty źródłowe

Cronaca di Anonimo Veronese I446-I488, red. G. Soranzo, Venezia I9I5.

Geoffroy Tour De La Landry, The Book of the Knight of La Tour-Landry: Compiled for the Instruction of His Daughters, London I868.

Gli Experimenti de la ex.ma S.ra Caterina da Furlj, matre de lo inllux.mo signor Giovanni de Medici, copiati dagli autografi di lei dal conte Lucantonio Cuppano colonnello ai servigli militari di esso Giovanni de’Medici detto delle Bande Nere, Imola I894. 
Il libro di Metrodora sulle malattie delle donne e ricettario di cosmetica e terapia, ed. trad. it. G. Del Guerra, Milano 1953.

Libro di M. Giovanni Boccaccio delle donne illustri. Tradotto di latino in volgare per M. Giuseppe Betussi, con una giunta fatta dal medesimo, d'altre donne famose. E un'altra nuova giunta fatta per M. Francesco Serdonati d'altre donne illustri. Antiche e moderne. Con due tavole una de nomi, e l'altra delle cose più, Fiorenza per Filippo Giunti I596.

Metrodora, Medicina e cosmesi ad uso delle donne: l'antica sapienza femminile e la cura di sè, introduzione Del Guerra G., Milano I994.

Trotula. Un compendio medievale di medicina delle donne, red. M. H. Green, Firenze 2009.

Opracowania

Chłędowski K., Rzym: Ludzie odrodzenia, Warszawa 1957.

Franceschini G., Caterina Sforza e il tramonto della Signoria su Imola e Forli, Bologna I967.

Głusiuk A., Dbałość o urodę kobiet na podstawie traktatów Metrodory z Bizancjum i Trotuli z Salerno, „Seminare”, 20I8, nr I, s. I45-I54.

Głusiuk A., Higiena kobiet w jedenastowiecznej Italii na podstawie nauk Trotuli z Salerno, w: Czystość i brud. Higiena w średniowieczu, red. W. Korpalska, W. Ślusarczyk, Bydgoszcz 20I4, s. 97-I09.

Graziani N., Venturelli G., Caterina Sforza, Milano $200 \mathrm{I}$.

Ieraci Bio A.M., Testi ginecologici tra Oriente ed Occidente I. Metrodora ed il Dynameron di Nicola Mirepso II. Una testimonianza italo-greca su una Quaestio medicalis salernitana, w: La Scuola Medica Salernitana. Gli autori e i testi. Convegno Internazionale (Università degli Studi di Salerno, 3-5 novembre 2004), red. D. Jacquart, A. Paravicini Bagliani, Firenze 2007, s. 283-3I4.

Maderna E., Medichesse. La vocazione femminile alla cura, Aboca $20 \mathrm{I} 4$.

Parker H.T., Women Doctors in Greece, Rome, and the Byzantine Empire, w: Women Healers and Physicians: Climbing a Long Hill, red. L.R. Furst, The University Press of Kentucky I997, S. I3I-I5O.

Parker H. Women and Medicine, w: A Companion to Women in the Ancient World, red. S. L. James, S. Dillon, Malden, Oxford, Chichester 20I2, s. I07-I24.

Pasolini P.D., Caterina Sforza, t. I-3, Roma I893.

Power E., L'educazione delle donne, w: Né Eva né Maria. Condizione femminile e immagine della donna nel Medioevo, red. M. Pereira, Zanichelli, Bologna I98I, s. IOI-III.

Power E., Donne nel medioevo, red. M. M. Postan, Jaca Book, Milano I9994.

Roatti N., Della Famiglia Sforza, t. 2: Donne illustri di Casa Sforza, Roma 1794.

Rowland I.D., The amazing afterlife of Cleopatra's love potion, w: Cleopatra: A Sphinx Revisited, red. M.M. Miles, University of California Press 20II, s. I32-I49.

Rudowska I., Kosmetyka wczoraj $i$ dziś, Warszawa 1989.

Vita di Caterina Sforza Riario contessa d'Imola e signora di Furli descritta in tre libri dall'abate Antonio Burriel, t. I, Bologna I795. 